\title{
MENINGIOMA OF THE INTERNAL AUDITORY CANAL
}

\section{Case report}

\author{
Marcelo Campos Moraes Amato ${ }^{1}$, Benedicto Oscar Colli ${ }^{2}$, Carlos Gilberto Carlotti Junior ${ }^{3}$, \\ Antonio Carlos dos Santos ${ }^{4}$, Maria Cristina Lancia Cury Féres ${ }^{5}$, Luciano Neder ${ }^{6}$
}

\begin{abstract}
Meningiomas limited to the internal auditory canal (IAC) are rare. Acoustic neuroma is usually the diagnosis made when a tumor is found in this location because of its higher frequency. We report on a 58 year-old woman with a meningioma arising from the IAC and the difficulty to establish the pre-surgical diagnosis, based on clinical and radiological features. The perioperative suspicion and confirmation are very important to deal with the dura and bone infiltration in order to reduce tumor recurrence.
\end{abstract}

KEY WORDS: meningioma, internal auditory canal, acoustic neuroma.

\begin{abstract}
Meningioma do meato acústico interno: relato de caso
RESUMO - Meningiomas restritos ao meato acústico interno são raros. O neurinoma do acústico é o principal diagnóstico diferencial feito quando um tumor é encontrado nesta região devido a sua maior freqüência. Apresentamos o caso de uma mulher de 58 anos de idade com meningioma localizado no meato acústico interno e as dificuldades na realização do diagnóstico pré-operatório considerando-se as apresentações clínica e radiológica. A suspeita e a confirmação do diagnóstico intraoperatório são importantes porque a dura subjacente e eventual osso comprometido devem ser ressecados para reduzir a possibilidade de recidiva.
\end{abstract}

PALAVRAS-CHAVE: meningioma, meato acústico interno, neurinoma do acústico.

Meningiomas are the second most common tumor of the cerebellopontine angle (CPA) accounting for 3.1 to $12 \%$ of all tumors following acoustic neuroma, which represent 76 to $91.3 \%$ of the total ${ }^{1-3}$. Usually CPA meningiomas arise from the dura of the petrous bone and are classified according to their origin, in relation to the International Auditory Canal $(\mathrm{IAC})^{4}$. Meningiomas arising within the IAC are considered rare; only 22 cases of these tumors were reported in the literature ${ }^{4-18}$, eleven cases were limited to the IAC, while the others also extended to the CPA. Controversy exists in the literature if the meningioma can arise within the IAC or its involvement occurs secondarily by extension of CPA tumors ${ }^{5}$. The first histologically proven case of a purely intracanalicular meningioma was reported by Virchow in $1863^{6}$.

In the present report we describe a meningioma of the IAC and the difficulty to establish the preo- perative diagnosis, since the clinical findings can simulate an acoustic neuroma and the radiological examination can also be quite similar-13,18. The surgical strategy is also discussed.

\section{CASE}

A 58 year-old female presented in May 2002 with a 2month history of sudden hearing loss and tinnitus on the right. A retro-cochlear disease diagnosis was made based on auditory examinations. The pure-tone audiometry revealed a left descendent sensorineural hearing loss, mild at 500 and $1000 \mathrm{~Hz}$ and severe at $8000 \mathrm{~Hz}$. The right speech discrimination score was $72 \%$ with monosyllables and $92 \%$ with disyllables, the left year score was $100 \%$ with monosyllables. The imitanciometry revealed a bilateral A curve at the tympanogram. The acoustic contra lateral reflex was absent at all frequencies in the right, and present in the left ear. The MRI revealed an enhanced lesion in the IAC projecting outside the porus measuring

${ }^{1}$ Medical Student, Department of Surgery and Anatomy, Ribeirão Preto Medical School, University of São Paulo, Ribeirão Preto SP, Brasil (FMRP-USP); ${ }^{2}$ Professor - Department of Surgery and Anatomy, Head of Division of Neurosurgery, FMRP-USP; ${ }^{3}$ Assistant Professor - Department of Surgery and Anatomy, FMRP-USP; ${ }^{4}$ Assistant Professor - Division of Radiology, FMRP-USP; ${ }^{5}$ Assistant Professor - Department of Ophthalmology, Oto-Rhino-Laryngology and Head and Neck Surgery, FMRP-USP ${ }^{6}$ Assistant Professor - Department of Pathology, FMRP-USP.

Received 27 December 2002, received in final form 12 March 2003. Accepted 26 March 2003.

Dr. Benedicto O. Colli - Departamento de Cirurgia HCFMRP - Campus Universitário USP - 14048-900 Ribeirão Preto SP - Brasil. E-mail: bocolli@fmrp.usp.br 

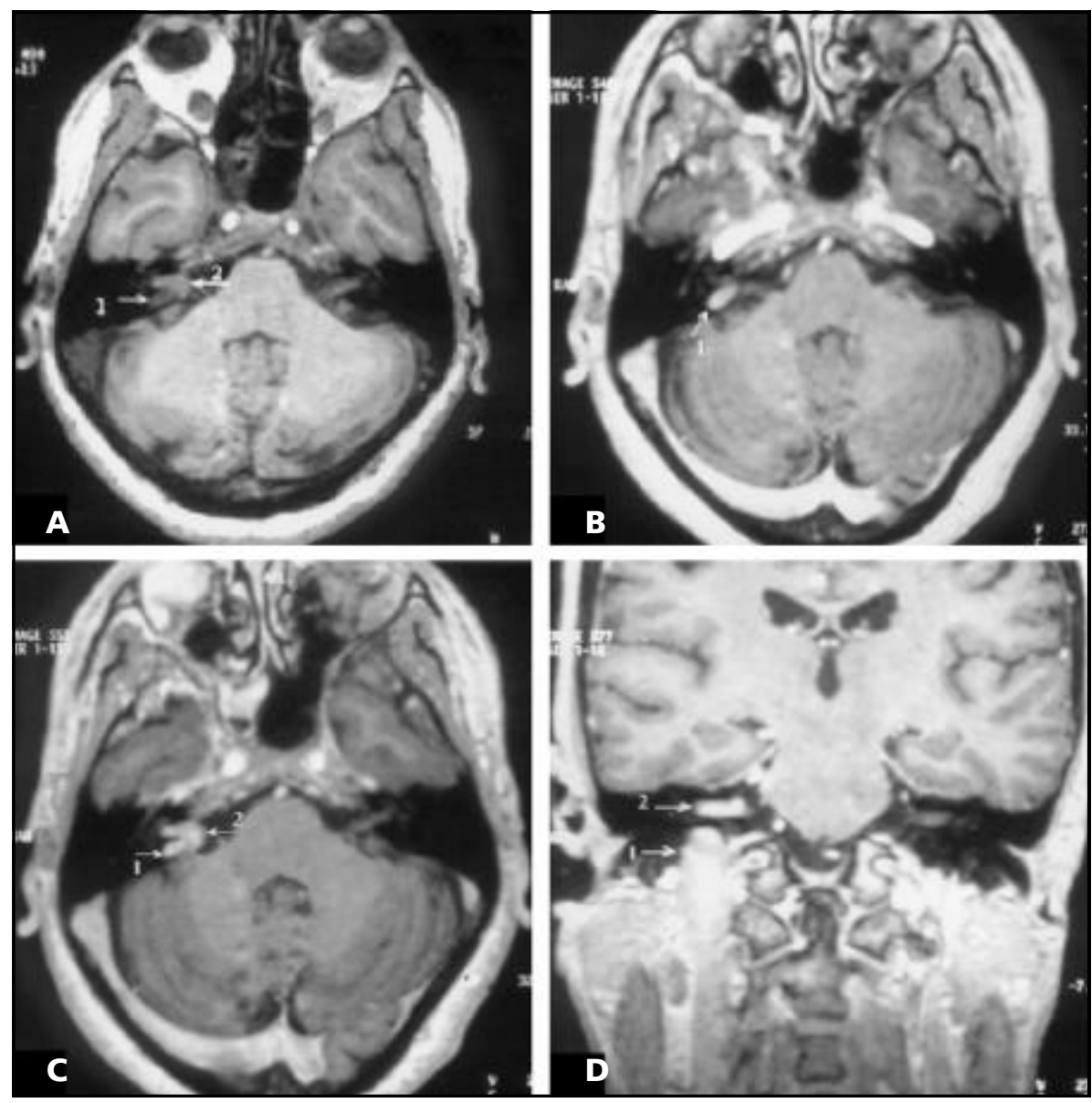

Fig 1. 3D-gradient echo sequence pre $(A)$ and post-contrast $(B-D)$. The internal jugular vein's bulb (arrow 1) is prominent and a mass with $12 \times 3 \times 7 \mathrm{~mm}$ is involving the VII-VIII nerve complex (arrow 2). An intense enhancement can be observed after gadolinium injection, $C$ and $D$.

$12 \times 3 \times 7 \mathrm{~mm}$ (Fig 1). A pre-operative diagnosis of acoustic neuroma was made.

A right retromastoid suboccipital approach was performed. Since the position of the jugular vein bulb was high, the IAC could not be completely exposed due to massive bleeding. In spite of the limited vision, the tumor was apparently totally removed and the subjacent dura was partially resected and coagulated. The patient awakened well from surgery with no additional deficits. The postoperative period was uneventful. The histopathological studies revealed a benign meningothelial neoplasia characterized by cells arranged in sheets and whorls, psammoma bodies was also a feature. The nuclei were round and oval presenting pseudo-inclusion. These findings were consistent with meningioma (Fig 2).

At her most recent visit to the outpatient clinic, she reported hearing improvement and absence of tinnitus, although the auditory examination remained unchanged.

\section{DISCUSSION}

Meningiomas are known to originate from the arachnoid villi lining cells and often arise along the dural venous sinus where arachnoid granulations are found. Petrous bone meningiomas are those that most commonly originate from the arachnoid granulations associated with the venous sinus (sigmoid sinus, torcula, superior petrosal sinus, and inferior petrosal sinus) $)^{5}$. These granulations also occur along the cranial nerves foramens and have been found inside the $I A C^{14,18}$, making possible the occurrence of IAC meningiomas. Higher frequency than reported in the literature can be speculated for these tumors, based on the difficulties in their diagnosis ${ }^{1,4,9,13}$. Because of its particular behavior, meningioma within the temporal bone invades widely and is more extensive than it macroscopically seems. It can follow cranial nerves to end organs, and spread widely throughout the perilabyrintine marrow and air cells ${ }^{5,19}$. The inner ear invasion propensity associated with the lateral extension of meningiomas deserves carefully radiological and intra-operative evaluations ${ }^{5,14}$. In spite of its tendency to invade the dura and the bone, meningiomas are considered benign and their symptoms are primarily caused by the 


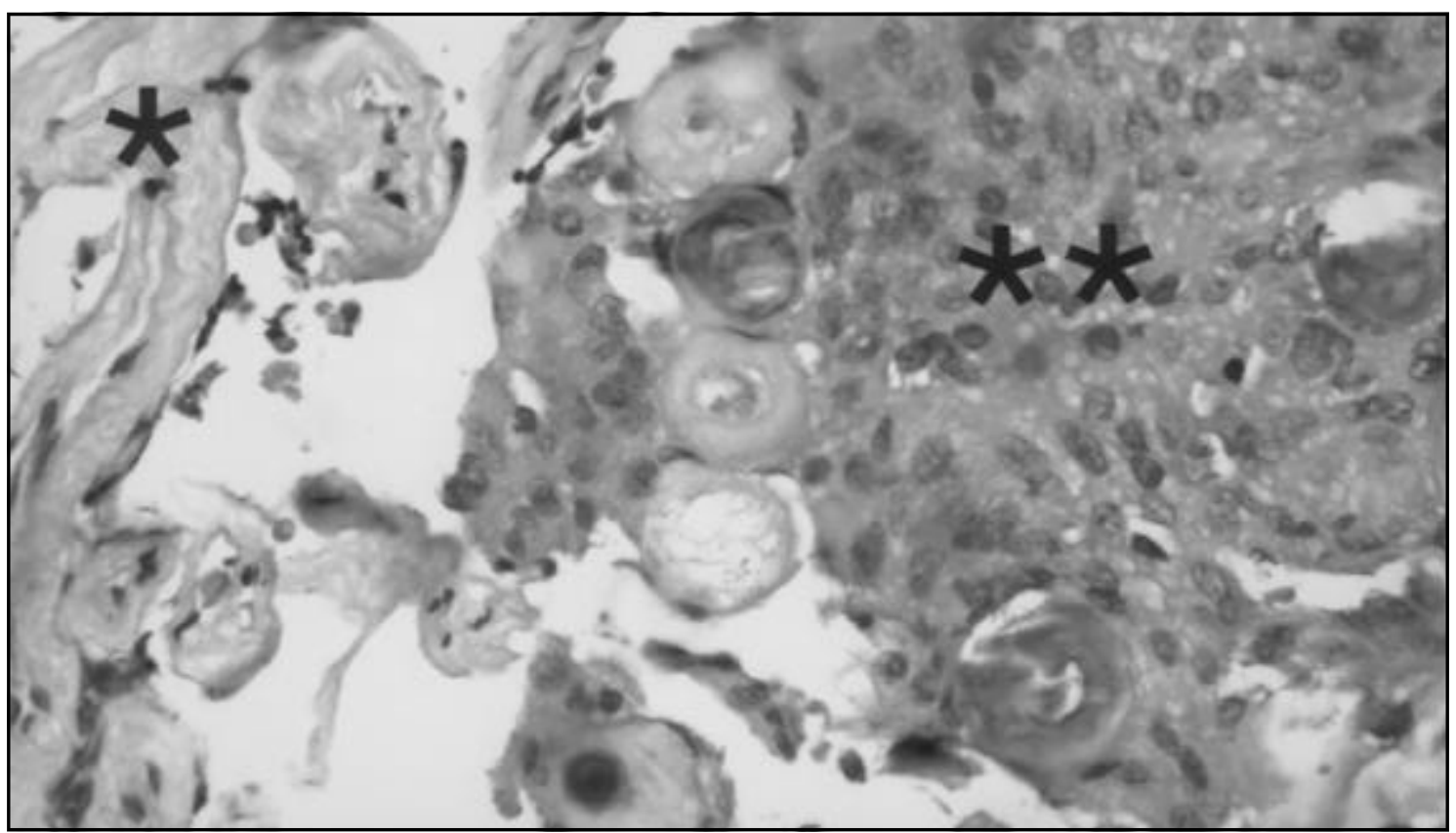

Fig 2. Photomicrograph showing the neoplasm composed by meningothelial cells with several psammoma bodies (**) and adjacent dura mater (*). Original magnification $X 400$.

neighboring neural structures compression ${ }^{15}$. This peculiarity allows meningiomas to grow asymptomatic in large space areas, such as the CPA. However, inside the IAC the symptoms come earlier, since there is limited available space and the labyrinthine bone is commonly invaded, what may cause facial nerve and inner ear dysfunction ${ }^{14}$.

The symptoms, physical findings and audio-vestibular tests results most commonly found are: sensorial hearing loss, tinnitus, unsteadiness, dizziness, vertigo, hemi facial paresis, speech discrimination incapability, negative response on the vestibular caloric test and abnormal response to pure-tone audiometry. Concerning to the clinical findings, the only relevant difference between the IAC meningiomas and acoustic neuromas is the more common involvement of the facial nerve in the former ones $5,10,18$.

On neuroimage studies, acoustic neuromas and IAC meningiomas are mostly isointense or slightly hypointense to the white matter on T1-weighted images. On T2-weighted images, neuromas tend to be isointense, whereas meningiomas tend to be hyperintense. Both tend to show a high enhancement after gadolinium administration 4-10,13,17,18. In CPA meningiomas other radiological signs as dural tail, hyperostosis, broad base, lack of IAC enlargement may be useful for the diagnosis, however, these particularities are hardly seen in such small tumors ${ }^{5,11,20}$. Small cysts are more common in acoustic neuromas but are seen only in large tumors $\mathbf{s}^{6,20,21}$.
The position of the tumor related to the VII and VIII nerve complex seems to be the greater trace of a non neuroma lesion inside the IAC. In acoustic neuroma the neural complex lies anterior or anterosuperior to the tumor, while an IAC meningioma does not hold a fixed relation with the nerves, but the majority of IAC meningiomas lies anteriorly within the canal and displaces the nerves posteriorly $6,8,11,22$. In the presented case this relationship could not be established. As reported previously, no continuity of the tumor with the vestibular nerve was observed during the surgery of our patient, and the tumor was found to be adherent to the dura-mater of the porus, what suggested the diagnosis of a meningioma. That hypothesis was confirmed by a perioperative histopathological examination.

In a large series of cranial and spinal meninigomas, recurrence rate after a grossly complete excision was $7 \%, 20 \%$ and $32 \%$ after 5,10 and 15 years, respectively; and residual lesion was the most important factor of recurrence ${ }^{23}$. Although it is not known whether intracanalicular meningiomas tend to behave the same way, it is important to consider it as a differential diagnosis ${ }^{5,9,13}$. Its histopathological confirmation during surgery gives the surgeon the opportunity to reduce meninigiomas recurrence rate by accomplishing a wide dural excision with complete tumor resection and removing 5 to $10 \mathrm{~mm}$ of bone from its attachment ${ }^{5,20}$. In the presented case, the IAC posterior wall opening was very difficult due 
to an anatomic variation of the internal jugular vein bulb that was found to be prominent and elevated. In spite of the reduced visualization, the tumor excision was apparently completed and the dural implantation was removed and coagulated.

Hearing recovering has been reported after meningiomas removal, as in our case, and it is consistent with the theory that symptoms caused by meningiomas are due to neighboring structures compression and not by their invasion ${ }^{6,8}$.

In conclusion, we presented a case of difficult preoperative diagnosis and that neurosurgeons must be aware to establish the diagnosis during the surgery to avoid tumor recurrence.

\section{REFERENCES}

1. Brackmann DE, Bartels LJ. Rare tumors of the cerebellopontine angle. Otolaryngol Head Neck Surg 1980;88:555-559.

2. Moffat DA, Saunders JE, McElveen JT, McFerran DJ, Hardy DG. Unusual cerebello-pontine angle tumours. J Laryngol Otol 1993;107:1087-1089.

3. Thomsen J. Cerebellopontine angle tumours, other than acoustic neuromas. Acta Otolaryngol 1976;82:106-111.

4. Caylan R, Falcioni M, Donato G, et al. Intracanalicular meningiomas. Otolaryngol Head Neck Surg 2000;122:147-150.

5. Ishikawa N, Komatsuzaki A, Tokano H. Meningioma of the internal auditory canal with extension into the vestibule. J Laringol Otol 1999;113:1101-1103.

6. Bohrer PS, Chole RA. Unusual lesions of the internal auditory canal. Am J Otol 1996;17:143-149.

7. Devesa PM, Wareing MJ, Moffat DA. Meningioma in the internal auditory canal. J Laringol Otol 2001;115:48-49.

8. Dinh DH, Clark SB, Whitehead M, Amedee R, Bhattacharjee MB. Intracanalicular meningioma. South Med J 2000;93:618-621.
9. Haught K, Hogg JP, Killeffer JA, Voelker JL, Schochet SS Jr. Entirely intracanalicular meningioma: contrast-enhanced MR findings in a rare entity. Am J Neuroradiol 1998;19:1831-1833.

10. Hilton MP, Kaplan DM, Ang L, Chen JM. Facial nerve paralysis and meningioma of the internal auditory canal. J Laring Otol 2002;116:132-134.

11. Hodgson TJ, Kingsley DPE. Meningioma presenting as a mass in the internal auditory canal. Neuroradiology 1995;37:479-480.

12. Hooper R, Siu K, Cousins V. Temporal bone meningiomas. Aust N Z J Surg 1990;60:779-786.

13. Zeitouni AG, Zagzag D, Cohen NL. Meningioma of the internal auditory canal. Ann Otol Rhinol Laryngol 1997;106:657-661.

14. Langman AW, Jackler RK, Althaus SR. Meningioma of the internal auditory canal. Am J Otol 1990;11:201-204.

15. Brookler KH, Hoffman RA, Camins M, Terzakis J. Trilobed meningioma: ampulla of posterior semicircular canal, internal auditory canal, and cerebellopontine angle. Am J Otol 1980;1:171-173.

16. Singh KP, Smyth GDL, Allen IV. Intracanalicular meningioma. J Laryngol Otol 1975;89:549-552.

17. Bassi P, Piazza P, Cusmano F, Menozzi R, Gandolfi A, Zini C. MR cisternography of the cerebello-pontine angle and internal auditory canal in diagnosis of intracanalicular acoustic neuroma. Neuroradiology 1990;31:486-491.

18. Asaoka K, Barrs DM, Sampson JH, McElveen Jr., Tucci DL, Fukushima $\mathrm{T}$. Intracanalicular meningioma mimicking vestibular schwannoma. Am J Neuroradiol 2002;23:1493-1496.

19. Nager GT, Massica DN. Meningiomas of the cerebello-pontine angle and their relation to the temporal bone. Laryngoscope 1970;80:863-895.

20. Lalwani AK, Jackler RK. Preoperative differentiation between meningioma of the cerebellopontine angle and acoustic neuroma using MRI. Otolaryngol Head Neck Surg 1993;109:88-95.

21. Weber AL. Magnetic ressonance imaging and computed tomography of the internal auditory canal and cerebellopontine angle. Isr J Med Sci 1992;28:173-182.

22. Breuer T, Gjuric M, Wigand ME. Extended middle fossa surgery for meningiomas within or at the internal auditory canal. Am J Otol 2000;21:729-734.

23. Mirimanoff RO, Dorsoretz DE, Linggood RM, Ojemann RG, Martuza RL. Meningioma: analysis of recurrence and progression following neurosurgical resection. J Neurosurg 1985;62:18-24. 